\title{
Reading the Death in Literary Works (A Comparison between "Dokter dan Maut" and A Christmas Carol)
}

\author{
Sudarmoko \\ Department of Malay-Indonesian Interpretation and Translation \\ Hankuk University of Foreign Studies, Korea 89, Wangsan-ri, Mohyeon-myeon, \\ Cheoin-gu, Yongin-si, Gyeonggi-do, Korea, 449791 \\ e-mail: sudarmoko@fsastra.unand.ac.id
}

\begin{abstract}
This paper compares two literary works written by an Indonesian and a British author. There are some different points of views regarding the phenomenon of death in these literary works. In contrary, there are also similarities between the two texts. Social, cultural and religious backgrounds influence the way of looking at and discussing the theme and the different way of solving a problem as well. This comparison of literary works provides an example of how an Indonesian and British person deal with the same theme in their literary works and make differences in terms of exploring the theme in their works.
\end{abstract}

Key words: comparative literature, Indonesia and British, the death, prose

In this paper I would like to discuss the phenomenon of death in literary works. ${ }^{*}$ This discussion is based on two works of Navis' short story (2002, pp. 1-24) and Charles Dickens’ novel (first published 1843). Both works tell the phenomenon of death and how people face the angel of death. I chose these stories with the intention of comparing the way of looking at the same theme from a different background, namely cultural and religious background. The first story was written by an Indonesian Muslim man and the second by a British Christian person. This

\footnotetext{
* This work was supported by the Hankuk University of Foreign Studies Research Fund 2010. Shorter version of part of this article has been published in Kompas, March 13, 2005. I would like to thank Aone van Engelenhoven for his comments and correction of early draft of this article. I would also like to acknowledge the help of Donny Sofyan for editing the language of this paper.
} 
comparison is a basis for finding differences in using metaphors and deriving diverse meanings from them. For this reason, the discussion is focused on the metaphors of death.

Death is a mystery of life. People have different ways of looking at death. From a religious point of view, death is a life circle differently phrased in each religion. Death cannot be avoided by people because it is an obligatory consequence of human life. People also have different interpretations of the death phenomenon. This difference is based on the culture, religion, or environment which influences the people's frame of mind. For example, Hindus think that death is a phase of change for the soul to achieve a better place, called nirvana. So, death is just a step to rebirth, after which the soul finds a better life according to Hindu teachings. Good deeds are as a condition for the soul of entering nirvana based on Hindu teaching.

In some societies, death ceremonies are more important than other ceremonies such as ceremonies related to birth or marriage. For instance, in Tana Toraja, it takes a long time to complete a death ceremony and also requires a lot of money. Many philosophers also propose the problem of death. Yet, from philosophical point of view, this phenomenon is more complicated and has a relationship with other problems such as time, space, material, and the essence of life. In short, the phenomenon of death remains an unsolved theme explored by most fields of studies and demands a lot of attention from experts, scholars, students and religious thinkers.

Actually, death in literary works is a central theme, even though it is mostly unexplored by critics or scholars. For example, Elisabeth Bronfen and Sarah Webster Goodwin (1993, p. 10) say that death is the major agon of the psyche, the major subject of the text. No consideration of psychic representation can afford to ignore or deny the centrality of death to the psyche's self-construct, just as semiotics can suppress the positioning of the sign in reference to the non-semiotic, the perpetually resistant reality that death represents. This phrase indicates the important role of the death theme in literary works. Perhaps, amidst the lack of information sources and references, this paper may give a simple contribution to literary criticism, especially in comparative literature and Indonesian literature on the whole.

As a real life phenomenon in literary works, death is still an interesting theme worth of exploring. An interesting phenomenon is the exploration of death in the literary works with war being the theme and 
setting. Many people got injured or died in wars. But many authors wrote literary works based on these wars, and we as readers are interested in these works. As Coffman (2003) notes that:

Death itself remains unknowable. Rather than assume an impossible understanding of death, the war poems explore the fuzzy territory that lies between the dead and the denial of death. Although the effect of life by death may not be dramatic effect the writer or reader was expecting, death may nevertheless cause subtle inflections in the lives of those who survive close contact with it (p. 74).

As a mystery, death is an interesting theme in literary works written by authors. Some readers also like reading books that explore death. For example, detective novels often present the mystery of dead people. Even though they are not talking about the phenomenon of death itself, they give an interesting mystery of human life, the mystery of death. Another fact shows that death is something explored in entertainments of any kind and readings at any age. Cartoon or animated movies for kids present sadism and death covered by humor and games. We can find such death events easily nowadays. But, there have been few references that talk about this phenomenon.

One of the short stories compiled in AA. Navis' Bertanya Kerbau pada Pedati (A Cow Asks the Cart) (2002) is entitled Dokter dan Maut (Doctor and Death). The story narrates a dying Doctor and the situation around his family, showing their attitudes and the family members' reaction to his properties after his death. The story begins when one day the Doctor comes home from his hospital. He sees his families are crying and does not know why. He does not realize what is going on in his house and why people are talking as if he is already dead.

A person pays him a visit, the angel of death. He introduces himself as a patient of the Doctor who was cured by him several years ago. He invites the Doctor to go around and look at what his family does. Later he knows what his family has planned to his properties and heritage. His family has some plans for their own interests. The Doctor understands that he is really dying and the person at his side is the angel of death. Having known what is happening around him, he chooses to get into afterlife, when the angel of death offers him whether to stay alive or go with him. 
Dickens' story, A Christmas Carol, is taken for a comparison. The story tells about a character, Scrooge, who does not believe in Christmas and has a bad behavior toward his employees in his office. One day he is visited by his former employers, who were already dead. The employers are telling him about angels who will come soon and bring death to Scrooge. Then the angels come, one by one, and show him his previous experiences. Each angel has a special focus on showing Scrooge's personal deeds. Having known his bad deeds and after the last angel shows his grave with Scrooge's name written on it, Scrooge actually wants to repay his deeds and asks for extra more time to do it. But the time, as it is determined, has its own pace in ruling nature and living things.

\section{PSYCHOLOGICAL AND PHYSICAL BODY}

The body in the world is a material and mortal thing. It represents a container that accommodates the soul in the world. The soul is immortal and eternal, according to different points of view. The body, at some condition and calculated time, will face its border. It will be destroyed in time. Even in some religious teachings, the existence of the body is not less important than the soul. The body is used in appropriate ways by the soul. The body is something given by the Creator. Basically, we have no power to create or manipulate the body.

There is no doubt that body and soul are separated things but united by the same agency. For example, the soul of the Doctor in Navis' story and that of Scrooge see clearer with the eyes of souls. The souls can see anything which cannot be seen by living eyes. The doctor can see the plans prepared by his family; proving the ability of the young understudy doctor in his hospital that he could not prove it before. The same conditions are also experienced by Scrooge's soul when it is invited by the spirit to look back at his previous life. He can see his nephew reading books, his previous friends, buildings, and places where he has been before.

Through these pictures, both authors propose an ideal of afterlife and death having better condition compared to the life on earth. The stories are not talking about life and afterlife. Rather, it deals with the coming period of death. They are talking about the crisis and span of time between life and death. In Doctor and Death, Navis, by considering the form and limitation of a short story, in short gives a dynamic and interesting experience of the Doctor. 
The process between death and life becomes a 'crisis' stage for one's life. This is the situation where one has to deal with a determined time provided by The Creator. It is the time where natural law ends the mortality. Because no one can avoid his/her death as a human being and live eternally, it might be wise to follow the rules as planned by nature or The Creator. Both authors implicitly tell that death is a must, but we can also see that life is also an important stage for human being. In life we can try to do valuable deeds as a capital to enter the afterlife. Both lives are definite according to some religious teaching and societies.

The difference between Navis' and Dickens' stories is that the main characters of each story have separate ways of facing death. In Navis' story, the Doctor prefers to get into the afterlife world considering he will have a better life and place in the afterlife thanks to his previous deeds. We can read in the passages below:

"Bagaimana Dokter? Apa Tuan masih ingin hidup lebih lama lagi?” Tanya Sang maut itu tetap dengan senyumnya. Senyum itu kian manis dalam pandangan dokter itu.

"Jika aku boleh mengulang hidupku sebagai orang muda, akan lain yang aku kerjakan. Takkan aku biarkan kebobrokan ini berlangsung terus. Tapi untuk hidup lebih lama sebagai orang tua, tanpa daya, oh, minta ampun,” katanya yakin.

Kini tubuhnya terasa demikian ringannya. Mati itu tidak dirasakannya seperti yang dikiranya selama ini. Mati hanyalah suatu perpindahan hidup. Namun hatinya sedih juga. Sedih yang lain. Sedih melihat tingkah laku orang-orang yang jadi sahabat dan kerabatnya sesudah kematiannya (Navis, 2002, pp. 23-24).

But in Dickens' story, Scrooge prefers to re-take some more time paying for his previous deeds. We can recognize it from the last passages of Stage Four:

Scrooge crept toward it, trembling as he went; and following the finger, read upon the stone of the neglected grave his own name, EBENEZER SCROOGE.

“Am I that man lay upon the bed?” he cried, upon his knees.

The finger pointed from the grave to him, and back again.

"No, Spirit! Oh no, no!” 
The finger still was there.

"Spirit!" he cried, tight clutching at its robe, "hear me. I am not the man I was. I will not be the man I must have been but for this intercourse. Why show me this. If I am past all hope?”

For the first time the hand appeared to shake.

"Good Spirit," he pursued, as down upon the ground he fell before it: "Your nature intercedes for me, and pities me. Assure me that I yet may change these shadows you have shown me, by an altered life." The kind hand trembled.

"I will honour Christmas in my heart, and try to keep it all the year. I will live in the Past, the Present, and the Future. The Spirits of all Three shall strive within me. I will not shut out the lessons that they teach. Oh, tell me I may sponge away the writing on this stone!”

In his agony, he caught the spectral hand. It sought to free itself, but he was strong in his entreaty, and detained it. The Spirit, stronger yet, repulsed him.

Holding up his hands in a last prayer to have his fate aye reversed, he saw an alteration in the Phantom's hood and dress. It shrunk, collapsed, and dwindled down into a bedpost (Dickens, 1843, p. 11).

Basically, the messages of these stories have a similar tension: provoking readers to think about life and behavior during their lifetime. What we did will be questioned in the future and we will be asked about our own responsibility. Both stories tell the same events when death is coming. Stories describe how people face death and connect it with their deeds.

\section{THE BODY OF HUMAN BEING}

In Navis' short story, human body is considered a material thing. It can be recognized when the soul of the Doctor sees his corpse on the bed. At first, the soul does not realize that it is his former body. He asks the angel whose body is laying on his bed. The angel answers that it is his body.

From this event we know that there is a distance between the soul and the body. The question proposed by the soul indicates the distance between the soul and the body. The metaphor of this picture brings us the scenario that the body stops at the end at death, and the soul continues its journey along its path. The separation of body and soul takes place at the moment of death. 
The body will be destroyed in its time while the soul is timeless. Time means the limited lifespan of things in the world and also the power and authority of God. The character of the Doctor in Navis' short story also becomes another metaphor of the body. The Doctor has a duty to help unhealthy people and take care of people who need medicine. But, Navis also gives an additional duty of the Doctor in his story by presenting pictures of the Doctor's activities. For instance, the Doctor also helps a man who wants to commit suicide because of his debacle of getting a wife. His girl friend died because of an accident. The Doctor advises a young girl losing her future because she was forced to marry a person she does not want. The Doctor succeeds not only in medical but also in humanist touch.

In fact, in many societies in Indonesia, people still treat bodies of dead people as good as possible. For example, Batak people erect ancestral monuments to remember deceased (Anthony Reid in Chamber-Loir and Anthony Reid, 2002, p. 91). People still visit or make a pilgrimage to saints' graves to ask for help, for instance the pilgrimage to wali songo (the nine holy people who firstly spread Islam in Indonesia, especially in Java). In this sense, Henri Chambert-Loir (2002) explains "most ask for something, say prayers, make offerings (flower petals, perfumed oil, incense), and take back something with them (water, earth, rice, ashes, pebbles); they will come back for a thanksgiving ceremony (selametan) when their request has been granted. Others meditate (semedi, tapa, tirakat, nyepi), and their petition is not for a specific reward (money, marriage, position) but for some progress in their spiritual life. Some even stay a few days beside the grave; they usually spend the nights praying. Moreover, some walk from one grave to another, in order to visit regularly one or a few places only because of a special spiritual affinity they have with the saint” (pp. 134-135).

Chambert-Loir's explanation gives a clear picture of how people treat and persuade the dead. They believe that important people, such as saints, village or country founders, heroes and ancestors, have supernatural power for helping living people. Perhaps this treatment is not found in other (western) countries. Remembering ancestors also establishes a kind of relation between the dead and the living. This can be found in every race and every time, but there is a divergence in treatment, based on each culture (Sudarmoko, forthcoming, 2011). 


\section{THE SOUL}

The soul in Navis' story is clearly explained as an immortal thing just as in Dickens' story. In both stories, the souls are brought by the spirit to look at the world's materials. By defining the purity of soul, authors state that, it also has a relation with death. Death in both stories shows the event of separation of body and soul, not of life and death itself.

It means that the life of a soul does not end as the angel of death comes. In the Navis' story, however, the Doctor's decision to follow the angel also serves as a metaphor. The Doctor prefers to go with the Angel rather than staying in the world. The reason for this option is that he is already old and has no power to change his life with his bad relatives. The Doctor's awareness of his body, being aging, suggest that, according to Navis, the body cannot do anything without the soul, especially when the body has reached its maximum usage concerning time or age. Seen from the story, when Navis allows the Doctor to go with the angel, it seems it is time to separate the body from the soul. This explanation has correlation with the reality, especially with the productive period of people doing activities in public and private companies, regulating the work period and pension, and managing retirement for employees.

The only one capable of communicating with the angel is the soul. Communication needs equal competence as mirrored in the following stories; the equality is shown by the same element (source of creation) of the soul and the angel. So, the conversation between souls and angels, at least, shows both soul and angel are the same. According to Islam, the soul is a light which gives life to human beings and all kinds of living things.

When the soul of the Doctor is invited by the angel, it looks at and talks to the angel as a guess. People around him do not see the angel; only the soul of the Doctor can see it. But in A Christmas Carol, Scrooge already prepared himself for the angels. When his colleagues warn him, he realizes that his guess is the angel. He can immediately recognize that he is facing the angels. But still only his soul can see the angels.

According to Christianity, the soul is a pure spirit which will return to God while the dead body turns back to its origin, dust. Hence, the common saying when it comes to burying dead people is dust turning back to dust. It refers to the mortal body. The soul is unlikely to fit the body forever. In both stories the souls in the beginning of death do not recognize their former bodies. What happens exactly from this set of guidelines is that 
body and soul are separated through the process of death. According to Clayton (Kabir, 2001, p. 32), the example of the unity of Mary's body and her soul in the pseudo John represents a cul-de-sac of sorts within the developing Transitus tradition in the Latin, which relied much more heavily on the sixth century text known. Mary's body and soul reunite and then place her body in paradise until the moment of judgment. From the Latin texts, there is an explanation on Mary's subsequent resurrection and corporal assumption into paradise rather than heaven, stating that the archangel Michael brings her soul back from a specified location and places it within her body in paradise.

\section{THE BODY OF ANGEL}

Angel does not have an exact form as soul does. According to some religions, an angel is made up of light and changeable. In particular, an angel can appear in any form, because it has ability to meet people in whatever form while carrying out the command of God. Also, people have different images of and beliefs about angels. These different pictures are created and maintained by religious stories to help their followers understand the religious teachings. Although angels have different images in many different places, the images are just a way to explain the existence of the angles to the followers according to their own language and cultural backgrounds.

In Dickens' story, the angels are able to bring the soul to the past. Their forms are different. The images or pictures of angels are also different, between one culture and another and between one religion and another. This difference is influenced by the frame of reference within a culture or religion. Each culture has its own frame of reference.

Soul and angel are immortal and stay strict to their own form of body given by their Creator. In other words, soul and body do not need any temporary body. The angel is created from light, meaning the light cannot be measured or formed in a special body. It simply can be perceived and felt. The bodies of soul and angel follow their function and form. In line with the pre-Christian idea, a spirit, which is another word of soul, has it own place or world. According to Vergouwen (as quoted by Chambert-Loir \& Reid, 2002), in the spirit's world, 
the spirits of deceased ancestors occupy a particular place, especially the spirits of those who, in their lifetime, became rich, had power and material goods and whose descendants are many. These spirits desire to be worshipped and honored with offerings in order to continue to be active in promoting the welfare of the descendants of these ancestors (p. 101).

In relation to soul and angel, both stories give a clear picture that only a soul can see angels. It does not matter whether a soul is good or bad. The story of Navis indicates that the Doctor has good attitudes, while Dickens' story shows that Scrooge emphasizes bad attitudes. The stories tell that an angel, in particular the angel of death, will come to people and then introduce themselves as an angel. The soul cannot avoid or escape from the angel, because its coming is a determined or must.

But in such traditional rituals dealing with ancestor souls, there are few (living) people who can see them, only the chiefs of rituals, for example, come to special peak stage (trance). These say that spirits are not fiction, but fact (Reid, 2002, p. 101). Several rituals show that souls of dead people still influence living people and give help or nuisance whenever they are asked for. Souls of dead people do not need to come with their previous bodies. They can come through other living bodies, for example, through a dancer or a dukun by means of special rituals.

Referring to Islamic teaching related to the form of souls, Muhammad Abduh says that souls are invisible beings whose basic elements cannot be known, but one must believe in their existence. We do not need to consider invisible details which are not explained by Allah and His prophets (Shihab, 2001, p. 59).

Braginsky (1993, p. 222) says that this is typical for the Malay world to distinguish in several parts body and soul. In correlation with spirit and soul, he writes that the system of Malay literature displays the same series of correspondences, namely the sphere of the soul, the sphere of the intellect, and the sphere of the spiritual heart. The only difference is that here the body and the soul (the carnal soul is conceived as a 'subtle' body) are united in a single whole. Indeed, in some places, the Malay world has ideas on philosophical themes that differ from Western philosophy. 


\section{RELIGIOUS POINT OF VIEW}

The phenomenon of death can also be considered from religious points of view. Religious teaching gives a picture on death for it believers. Death is a phase of life, a temporary place in order to continue for another world or life. People who died are considered as taking a break for a while. Death is a life between the world and afterlife. Religious teaching or beliefs in general, offer the theme of death as one of the main teachings for its followers because death and the afterlife are the most important parts for human beings. Life in the world is just a bridge or a means of gaining a better place in afterlife: heaven. Achieving a good place calls for heaps of conditions set by religious rules that must be obeyed by the followers.

Navis' short story is indicative of and bolstered by religious teaching. The process of death, according to common knowledge in society, depends on the deeds of a person in life. If someone has accomplished good deeds during his/her life, he or she would face an easy process of dying and the other way around. In Navis' story, the Doctor faces an easy process of dying. The author proposed good deeds as a background of the Doctor's case.

Another example closely bound to the source is that the angel has a friendly attitude towards doing its duty. The angel offers conversation and makes joke with the Doctor. In the Islamic story, the coming of the angel will trade on the attitudes and deeds of the person. If one had bad attitudes in his or her life, the form of the angel will scare him or her. But if the person had good attitudes, the angel will come in a friendly form. In $A$ Christmas Carol, the spirits have different forms when they come to Scrooge, indicating the situation and setting of the story or event taking place in the story. The process of death itself is a sign of the quality of life.

The view of Navis in his short story is much more influenced by the established opinion in society. The interesting point in both stories is that authors draw a picture of angels in human form. The conversation between people (souls) and angels, the habits of angels, and the way of warning for death, give us a picture that the angels are familiar to us. This familiarization used by the authors brings the spirits closer to us. We construe the picture of angels from their functions and duties as mentioned in holy books. From their duties, angels are more clearly pictured as people with human duties or occupations as we recognize people with diverse professions such as bankers, diplomats, farmers or teachers. 


\section{CONCLUSION}

The experience between life and death becomes an interesting story in Navis' story Doctor and Death and Charles Dickens' A Christmas Carol. Those stories tell that before the characters are really dead, they have the opportunity to visit their past and remember their experiences. Once this visit is over, in Navis' story, the main character decides to choose to enter the afterlife because he wants to achieve and experience another expected world. He feels that the afterlife would be better for him instead of staying with his tricky family. In the other way around, Scrooge basically wants to stay in this world and wants to carry out good deeds to repay his previous improper acts. Both choices represent different tendencies of people while facing their death. These two stories give us a reflection on the phenomenon of death which is important for us as human beings.

This paper has shown the comparison of two different literary works from different cultural and religious backgrounds. Besides having different values, both literary works have similarities in some aspects of literary values as well. The discussion of this paper enable us to draw any differences of those two works based on the backgrounds of authors, cultural settings, religions and other aspects. The thematic exploration in those literary works presented in this paper provides a picture of how the same theme, which is the death, becomes an interesting topic to be presented in Navis and Dickens' works. The death theme is universal, explored in every society, experienced by each human being, and in this discussion represented in literary works of different parts in the world.

\section{REFERENCES}

Braginsky, V. I. (1993). Universe-man-yext: The sufi concept of literature. Bjdragen tot de Taal-, Land-en Volkenkunde, 149, 201-225.

Chambert-Loir, H., \& Reid, A. (Eds.). (2002). The potent dead ancestors, saints and heroes in contemporary Indonesia. Honolulu: Allen \& Unwin and University of Hawai'i Press.

Coffman, M. D. (2003). Dark matters: Death, language, and human limitation in British first world war poetry. Stanford Honors Essay in Humanities, XLVII. 
Dickens, C. (1843). A christmas carol. Retrieved December 15, 2004, from http://www.stormfax.com/4dickens.htm

Goodwin, S. W., \& Bronfen, E. (Eds.). (1993). Death and representation. Baltimore and London: The John Hopkins University Press.

Kabir, A. J. (2001). Paradise, death and doomsday in Anglo-Saxon literature. Cambridge: Cambridge University Press.

Navis, A. A. (2002). Bertanya kerbau pada pedati. [A cow asks the cart]. Jakarta: Gramedia Pustaka Utama.

Shihab, M. Q. (2001). Perjalanan menuju keabadian kematian, surga dan ayatayat tahlil. [A passage to the eternal death, heaven and tahlil verses]. Jakarta: Lentera Hati.

Sudarmoko, (2005, March 13). Membaca kematian dalam Sastra. [Reading the death in literary work]. Kompas.

Sudarmoko, forthcoming. (2011). Fundraising management in death rituals in Indonesian society. Asia Pacific Journal of Business, Kangwon National University, 1(1). 